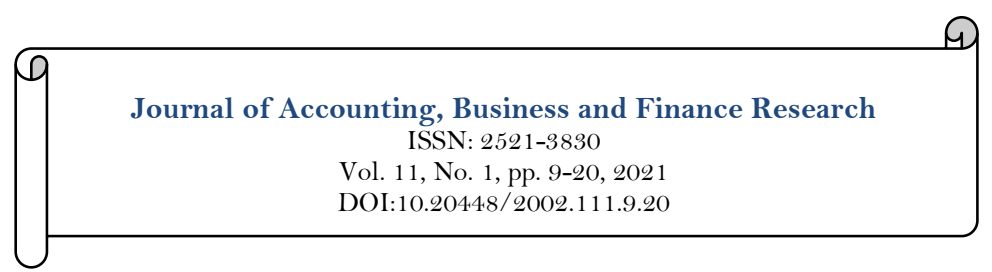

\title{
Reciprocal Use of Artificial Intelligence in Audit Assignments
}

\author{
Gultom, Juan Barus ${ }^{1 *}$ \\ Murwaningsari, Etty ${ }^{2}$ \\ Umar, Haryono ${ }^{3}$ \\ Mayangsari, Sekar
}

'Student at Doctoral Degree of Accounting, Trisakti University, Jakarta, Indonesia.

Email:juanbarusgultom@gmail.com

'Professor at the Faculty of Economics, Trisakti University, Jakarta., Indonesia.

${ }^{s}$ Professor at the Perbanas Institute, Jakarta, Indonesia.

${ }^{4}$ Lecturer in Doctoral Degree of Accounting, Trisakti University, Jakarta, Indonesia.

\begin{tabular}{|c|c|}
\hline \multirow{2}{*}{\multicolumn{2}{|c|}{ Abstract }} \\
\hline & \\
\hline $\begin{array}{l}\text { The purpose of this study is to examine the use of artificial } \\
\text { intelligence to improve audit quality and the effect of auditors' } \\
\text { competence and skepticism on client satisfaction. The purposive } \\
\text { sampling method was chosen deliberately based on specific criteria } \\
\text { determined by the researcher. The main source of data used in this } \\
\text { study comes from primary data collected via questionnaires that } \\
\text { were distributed directly via email to each respondent. Respondents } \\
\text { in this study are middle-level management who were involved in the } \\
\text { audit of companies listed on the Jakarta Stock Exchange. The sample } \\
\text { in this study comprises } 229 \text { respondents who responses were } \\
\text { processed and analyzed using partial least squares structural } \\
\text { equation modeling (PLS-SEM). This research is based on the Society } \\
\text { 5.O era, where data connects and moves everything; a system that } \\
\text { connects the virtual world and the real world. The era of the fourth } \\
\text { industrial revolution is where the discovery of the Internet of Things } \\
\text { (IoT) allows the interconnection between machines, big data, } \\
\text { acquisition, machine learning, smart factories, among others, and } \\
\text { financial reports to be made using a computerized system. The } \\
\text { Covid-19 pandemic has had an impact on almost all sectors and has } \\
\text { caused restrictions on many activities. As a result of the coronavirus, } \\
\text { a large number of activities or work are now carried out from home. } \\
\text { The results of this study prove that the effect of the application of } \\
\text { artificial intelligence combined with auditor competence and } \\
\text { professional skepticism create client satisfaction. }\end{array}$ & $\begin{array}{l}\text { Keywords: } \\
\text { Artificial intelligence } \\
\text { Auditor competence } \\
\text { Auditor's professional skepticism } \\
\text { Client satisfaction. } \\
\text { Licensed: } \\
\text { This work is licensed under a } \\
\text { Creative Commons Attribution } 4.0 \\
\text { License. } \\
\text { Publisher: } \\
\text { Scientific Publishing Institute } \\
\text { Received: } 10 \text { November } 2020 \\
\text { Revised: } 16 \text { December } 2020 \\
\text { Accepted: } 4 \text { January } 2021 \\
\text { Published: } 18 \text { January } 2021\end{array}$ \\
\hline
\end{tabular}

Funding: This study received no specific financial support.

Competing Interests: The authors declare that they have no competing interests.

Acknowledgement: The authors would like to thank their families, friends and all those involved who have shown

their unconditional support for their cause.

\section{Introduction}

This research discusses the use of artificial intelligence (AI) in the audit field. This study is vital because audit processes will be AI-based in the future (The Institute of Internal Auditors, 2017). The era of the fourth industrial revolution brought the discovery of the Internet of Things (IoT), which allows the interconnection between machines, big data, acquisition, machine learning, smart factories, among others, and financial reports are also created using a computerized system. When conducting an audit, auditors will experience difficulties 
in carrying out an objective assessment if it is done in a conventional or traditional manner. Since being announced by the WHO in early March 2020, the global Covid-19 pandemic has impacted almost all sectors and brought about the enactment of social restrictions to prevent the transmission of the Covid-19 virus. As a result, many people are now working from home (WFH).

This is the Society 5.0 era, where data connects and moves everything using a system that connects the virtual and real worlds. Auditor reports contain opinions that can create either client satisfaction or dissatisfaction. Satisfaction is a feeling of achievement and pleasure because expectations have been fulfilled. The level of satisfaction can be found by comparing the perception of the service received with the service expected. Client satisfaction is a reflection of a good image or reputation that is received and felt, if what is received by the client is in accordance with, or exceeds, their expectations. It is important to understand client satisfaction in relation to the quality of services provided by an auditor to survive and thrive in the face of competition.

The dynamic, changing world is moving toward the application of digitalization technology, creating innovations that are proven to be very strong, intelligent, scalable, and integrated to create the perfect collaboration between innovation, cognitive intelligence, and AI (Davenport, 2018). The Big Four public accounting firms have invested heavily in technological innovation. KPMG and IBM Watson have partnered to develop a tool called the artificial intelligence audit (Carlos, 2016). KPMG sees innovation in the world of auditing as not only a substitute procedure, but also as a series of continuous innovations, thus creating an evolutionary audit called KPMG Clara.

KPMG Clara can be continuously developed, and it has the ability to take advantage of new technology, which results in an increase in the level of insight available to KPMG auditors. The improved abilities of auditors can be in the form of analytical skills as well as predictive abilities that enable auditors to take information from various sources and apply it in the assessment of client businesses. One technological approach in the audit sector in recent years is cognitive technology. This is a type of AI which can read large amounts of data and perform a digital analysis of the available data in a way that is impossible with the current team of auditors.

One form of cognitive technology is the graphics processing unit (GPU), which is helpful in solving auditors' problems and provides additional resources for unlimited data processing (Davenport, 2018). KPMG has invested heavily in developing its audit capabilities in the last few years with its Dynamic Audit. The Dynamic Audit refers to electronic-based audits, increased data usage capabilities, data automation procedures, and data visualization.

The Dynamic Audit is an integral part of all members and auditors used to obtain audit evidence and define how auditors interact with clients in today's digital era. PricewaterhouseCoopers (PwC) have developed Halo, which is an analysis platform that serves as a medium for the creation of an efficient and quality audit process (Presswire, 2016). Deloitte has developed a tool called Argus to improve the capabilities of its auditors in analyzing available data. Ernst \& Young (EY) uses new technology to increase the meaning of AI and reduce its number of employees who usually perform traditional data processing (Harriet, 2016).

Along with the development of information communications and technology, other methods have been proposed, including computer-assisted auditing techniques. Therefore, increasing market pressure and competition have encouraged audit companies to provide benefits in terms of increasing competitiveness (Affes, 2016). The introduction of computerized systems in companies, growing competition, and the drive to maintain competitiveness has led audit firms to adopt new and more efficient procedures. Auditors can use AI to design audit work so that they can carry out structured and unstructured data analyses and use advanced analyses to draw a clearer view of possible risks and projected assets. Artificial intelligence is a cognitive technology involving algorithms that allow software to absorb information, reason, and think in a similar way to humans.

Analytical and predictive capabilities using cognitive technology enable auditors to visualize the impact of various audit scenarios on asset projections (Kokina \& Davenport, 2017) through the following stages: 1) Simplify and standardize data. Cognitive technology enables auditors to analyze unstructured data, and it can also improve the auditor's ability to obtain evidence and insights that enable them to make correct decisions and reach conclusions.

Cognitive technology allows auditors to obtain and analyze information not only from clients, but it can also digest data from other sources, such as print, digital, and social media, to get a clear understanding of a client's potential business risks (Davenport, 2018); 2) Digitizing and structuring data. Data acquisition is the essence of auditing. Auditors need to obtain raw data from a business before they can audit it, which means checking the accuracy and alignment of subsequent data sets. Auditors regularly examine external data sources to understand risks, audit plans, and confirm company statements. To incorporate artificial intelligence into an audit's methodology, auditors need to systematically understand how data sets are structured; in other words, how a structured data set differs from a single industry, client, or source system and how it reliably converts the data for use. 
Almost all business records today are stored electronically. Some data are easier to digest by software programs than others (text-based document files, pdf files, among others). Before the data set can be reconciled, there needs to be an interface to interpret and align the relevant data points across the shared file formats and, before today, the interfaces were both human and manual; 3) Automation technology. Compared with humans, machines excel at performing repetitive, time-consuming tasks such as data acquisition. Machines and technology that support AI will streamline data acquisition challenges faced by auditors. AI will minimize the workload and take less time to find relevant information, pull it from documents, and convert it into a usable format. AI systems can help auditors obtain and process data generated by financial reporting systems. AI can more quickly and completely identify patterns and anomalies in large data sets, and it offers more value from investigating and inferring the reasons behind patterns or anomalies.

AI will do what an auditor tells it to do; nothing more, nothing less; 4) Data analysis. AI in auditing makes it possible to move toward auditing $100 \%$ of data. Therefore, auditors will be empowered to study the entire business efficiently. AI can assist auditors move from traditional audit sampling frameworks to fullpicture visualization and evaluation. AI can help in most cases where intensive activities are carried out manually and it represents a significant transformation in traditional auditing, namely in data extraction, data comparison, and data validation.

AI can significantly speed up the digitization of data entry and extraction activities performed manually, reducing the time spent on audit data preparation. This delivers process efficiency, whereby clients spend less time and fewer resources responding to inquiries and documentation requests, and auditors have more time for risk analysis (Brennan, Baccala, \& Flynn, 2017); 5) Cognitive transformation.

AI technology, also called cognitive technology, can extend the power of information technology to carry out tasks traditionally performed by humans, enabling users of cognitive technology to solve the trade-offs between speed, cost, and quality (Raphael, 2015).

The sophistication of AI or cognitive technology will be meaningless if it is not balanced with competence. Competence is the skill, knowledge, basic attitude, and values which are reflected in a person's ability to think and act consistently. Competence is also the willingness to do what is known to produce benefits. Auditor competence refers to the skills needed to carry out an audit properly and ensure audit quality.

In summarizing audit engagements, the auditor's report must make a statement of opinion on the financial statements as a whole or deliver an assertion. If an overall opinion cannot be given, then the reasons must be put forward.

If the name of the auditor is associated with the financial statements, the auditor's report must contain clear instructions regarding the nature of the audit work carried out, if any, and the level of responsibility assumed by the auditor.

This scenario carries risks and requires the auditor's professional skepticism. Skepticism is a notion of always viewing something from an uncertain perspective, and disbelief or doubt about something that is not necessarily true. Skepticism is a doubtful attitude toward statements that are not sufficiently strong in evidence. Professional skepticism is the tendency to disagree with management's assertions without any corroborating evidence, or the tendency to ask management to provide facts on the assertions that are accompanied by evidence. Professional skepticism is an attitude that always questions and evaluates audit evidence critically, and an auditor's professional skepticism is crucial in improving audit quality.

Auditor reports contain opinions that can create client satisfaction or dissatisfaction. Satisfaction is achieved when the service received meets expectation. Client satisfaction is an important element of understanding the quality of services provided by an auditor to survive and thrive in the face of competition.

\section{Literature Review}

\subsection{Theoretical Framework}

The theory of perception is used in this research. Satisfaction can be measured by comparing the perception of the actual service received with the service expected. According to Langton Robbins (2006), "perception is a process used by individuals to manage and interpret their sense impressions in order to give meaning to their environment." Atkinson, Atkinson, and Hilgard (2000) argued that perception is the process by which humans interpret and organize stimulus patterns in the environment. Gibson, Ivancevich, James, and Donnelly (1994) explained that perception is the process of giving meaning to the environment by individuals. Langton Robbins (2006) argued implicitly that one person's perception of an object is likely to be different to another person's perception of the same object.

This phenomenon is due to several factors, namely perception and situation factors. Perception factors are influenced by attitudes, motives, interests, experiences, and expectations, while situation factors are influenced by time, circumstances, location, and social conditions. Krech, Crutchfield, and Livson (1974) stated that perception is influenced by personal and structural factors in addition to being heavily influenced by attention. 
Personal factors come from needs and past experiences that determine perception; it is not the type or form of stimuli, but the characteristics of the person who responds to the stimuli. Structural factors are derived solely from the nature of the stimuli and the effects they have on an individual's nervous system. Furthermore, attention is a mental process that occurs when a stimulus or series of stimuli become prominent in consciousness.

Client satisfaction is a reflection of a good image or reputation that is received and felt; if what is received by the client is in accordance with expectations or exceeds expectations, then the client will be satisfied. Client satisfaction is important and helps companies/service providers to understand the quality of services provided by auditors to survive and develop in the face of competition. Lovelock and Patterson (2015) define satisfaction as "a consumer's post-purchase evaluation of the overall service experience (process and outcome), specifically an affective state or a feeling reaction where the needs, wants, and expectations of consumers during the service experience have exceeded expectations". Iddrisu, Nooni, Fiankoc, and Mensah (2015) stated that "customer satisfaction refers to the extent to which customers are satisfied with the products and services provided by a business entity".

Burton, Sheather, and Roberts (2003) described customer satisfaction and dissatisfaction as "customer responses to perceived discrepancies between previous expectations or other performance norms and the actual performance of the product/service perceived after its use." According to Caruana (2002), client satisfaction includes three main constructs, namely expectation, performance, and disconfirmation. Expectations are what consumers believe will or should happen with regard to a product or service. Performance is the ability of a product or service to meet consumer needs and wants. Disconfirmation is a situation where expectations are higher than performance, while satisfaction is a condition where customer expectations of the performance of products and services are met.

2.2. Hypothesis Development

2.2.1. Effect of AI on Client Satisfaction

More complex data storage capabilities and the limited capabilities of auditors require the development of application systems to overcome these limitations. One tool that can help solve the problem of the limitations of accountants concerning technological advancements is cognitive technology.

AI offers efficient and inexpensive processes that improves the quality of an auditor's work; therefore, the improved quality of service will provide value for a company. An AI auditor will: 1) Increase the relevance of the audit; 2) Enable audit firms to expand their range of service offerings; 3 ) Improve audit quality, especially by being able to analyze all client data; 4) With digitization, bring the emergence of a new auditor profile; 5) Enable a culture of innovation in auditing firms, thereby improving corporate governance (Rodgers, Mubako, \& Hall, 2017).

AI is a tool that can improve the quality of audit services. Parasuraman, Zeithaml, and Berry (1994) explained that technology and equipment are tangible, so AI is a component that shapes the quality of audit services. A higher level of service quality results in a higher level of client satisfaction (Ohman, Häckner, and Sörbom, 2012), and client satisfaction is the center of organizational success (Minton, 2015); therefore, the following hypothesis is proposed:

Hor: An auditor's use of AI has a positive effect on client satisfaction.

\subsubsection{Effect of Auditor Competence on Client Satisfaction}

Competence is a personal attribute that allows for superior performance. Halim, Sutrisno, and Achsin (2014) revealed that auditor competence can be measured by four formative indicators, namely planning, knowledge, experience, and supervision. Planning is a vital aspect of an audit. An auditor's competence is determined by their planning ability. In addition, the audit plan must consider a company's internal control systems, audit risk, and substantive test procedures. Knowledge is one of the determinants of technical competence and is useful in structured auditor duties. In addition, the auditor's knowledge of accounting and audit procedures is critical in determining audit quality (Halim, 2014). One of the key indicators of auditor competence is experience and supervision. Experienced auditors will make judgments with a lower error rate than inexperienced auditors, thus affecting competence. Strong oversight will prevent auditors from acting in ways that reduce audit quality, and process-supervised audits are likely to result in correct disclosure and higher audit quality.

In this study, the focus is on the competence of auditors who have been appointed by a public accounting firm to conduct audits of clients (signing auditor competence). This is because their competence is crucial in determining the level of client satisfaction with the audit services performed. Not all auditors have sufficient knowledge of accounting and auditing rules and standards, and this has an impact on their clients' satisfaction (Ohman et al., 2012). The level of client satisfaction is influenced by both internal and external factors. Internal factors include the client's feelings regarding the services provided and the confidence instilled by the auditor. External factors include the reputation of the auditors and the public accounting firm where the auditors work. 
The greater these factors, the higher the client satisfaction will be (Ohman et al., 2012). Several previous studies have found a positive relationship between auditor competence and client satisfaction. It has been reported that "the ability of auditors to understand clients' business conditions and the industrial sector significantly affects clients' perceptions of audits conducted” by Carcello, Hermanson, and McGrath (1992); Humphrey and Ashforth (1994); Warming-Rasmussen and Jensen (1998); and Pandit (1999). It has also been reported that the content and thoroughness of the audit procedure (Windsor \& Ashkanasy, 1995); Jenkins and Lowe (2011) together with the auditor's problem-solving ability affect how the client perceives the work of the auditor (Behn, Carcello, Hermanson, \& Hermanson, 1997; Libby \& Tan, 1994). On the other hand, Ohman et al. (2012) found that signing auditor competence affects client satisfaction. According to DeAngelo (1981), competence is proxied by three aspects, namely knowledge, experience, and education. According to Armstrong and Baron (1998), competence is what people bring to a job in the form of different behaviors. Competence is therefore proxied by four main components: knowledge, experience, education, and behavior. Based on this explanation, the following hypothesis is proposed:

Ho: Auditor competence has a positive effect on client satisfaction.

\subsubsection{Effect of an Auditor's Professional Skepticism on Client Satisfaction}

Auditors need to have professional skepticism, especially when obtaining and evaluating audit evidence. Professional skepticism is the basis for achieving a high-quality audit performance. An auditor's professional skepticism, or doubts regarding client statements and information, both verbal and written, is part of the audit process. Ruiz, Gomez-Aguilar, De Fuentes-Barbera, and Garcia-Benau (2004) claim that an auditor's decisionmaking regarding a company's survival consists of two stages. The first stage identifies the issues related to the competence of auditors. The second stage, deciding what to do, is related to professional skepticism. This can occur because of the auditor's hesitation, but they must maintain their skepticism and ensure their client's satisfaction.

Auditor skepticism is a negatively related determinant of client satisfaction. Based on a qualitative approach, the client can perceive the auditor's skepticism as negative. In addition, research conducted by Ohman et al. (2012) found that auditor skepticism has a negative effect on client satisfaction; the higher the auditor's skepticism level, the higher the client's level of discomfort, which will decrease client satisfaction.

Hurrt, Brown, Early, \& Krishnamoorthy (2013) stated that professional skepticism is the basis for achieving a high-quality audit performance. (Hurrt et al., 2013) developed six characteristics of professional skepticism: 1) Critical thinking. The first characteristic of professional skepticism is that the skeptic's mind will question the reasons, adjustments, and evidence of something he has faced or obtained. 2) Suspension of judgment. The second characteristic of professional skepticism leads to behavior that delays drawing audit conclusions until sufficient evidence is gathered. This characteristic is formed from several indicators, such as requiring more information and time to make decisions, and not making decisions if all information has not been properly confirmed. 3) Search for knowledge. The third characteristic of professional skepticism is based on high curiosity.

This characteristic is formed from several indicators, such as in-depth searching for current information, and the auditor will not conclude or make a decision if not all information has been revealed. 4) Interpersonal understanding. The fourth professional skepticism characteristic can be conceived as the efforts of a skeptical person to understand the purpose, motivation, and integrity of the information provider. This will confirm whether the information provided is valid or not. This character is formed from several indicators, namely trying to understand the behavior of others and the reasons why someone behaves as they do. 5) Selfconfidence.

The fifth characteristic self-confidence in the form of self-direction and moral independence. A skeptical auditor believes in their professional ability to respond to and process all evidence that has been obtained. They prefer to find information by themselves and do not depend on the statements and information obtained. This characteristic is formed from several indicators, such as confidence in their own capacities and capabilities. 6) Self-determination. The sixth characteristic is the auditor's skepticism in objectively examining the evidence that has been gathered. They decide for themselves what evidence is needed to accept a particular hypothesis. This characteristic is formed from several indicators, such as indirectly accepting or justifying other people's statements, paying attention to other people's explanations and responses, finding inconsistencies, and not being easily swayed by others. Based on this explanation, the following hypothesis is proposed:

Hos: An auditor's professional skepticism has a negative effect on client satisfaction.

\section{Research Methods}

This research uses causal hypothesis testing, which tests the cause and effect between the dependent and independent variables (Sekaran \& Bougie, 2016). This method aims to produce a construct of a phenomenon based on the relationship model derived from the theoretical model. 
A quantitative approach was used, which relies on scores for analysis, which were obtained via the survey method. Kerlinger and Lee (2000) stated that this method can be used for large and small populations, but the data studied is from samples taken from those populations. Thus, the relative distribution and relationships between the variables can be determined.

\subsection{Measurement of Study Variables}

A closed questionnaire was used to collect data on the exogenous and endogenous variables and were submitted directly to the respondents in person or via e-mail. The answer choices were in the form of an ordinal numeric scale.

A numerical ordinal scale is used to measure the attitudes, opinions, and perceptions of a person or group regarding social phenomena. With a numeric ordinal scale, the variables to be measured are translated into indicators, which are used to arrange instrument items in the form of questions or statements. The measurements of the variables are shown in Table 1.

\begin{tabular}{|c|c|c|c|c|}
\hline Variable & Operational indicators & Measure & $\begin{array}{l}\text { Questionnaire } \\
\text { items }\end{array}$ & $\begin{array}{l}\text { Supporting } \\
\text { literature }\end{array}$ \\
\hline $\mathrm{AI}$ & Five tasks of AI & $\begin{array}{l}\text { 7-point ordinal } \\
\text { numerical scale }\end{array}$ & 5 & $\begin{array}{l}\text { Kokina and } \\
\text { Davenport (2017) }\end{array}$ \\
\hline $\begin{array}{l}\text { Auditor } \\
\text { competence }\end{array}$ & $\begin{array}{l}\text { Four proxies for the main } \\
\text { auditor competencies }\end{array}$ & $\begin{array}{l}\text { 7-point ordinal } \\
\text { numerical scale }\end{array}$ & 4 & $\begin{array}{l}\text { DeAngelo (1981); } \\
\text { Armstrong and } \\
\text { Baron (1998) }\end{array}$ \\
\hline $\begin{array}{l}\text { Auditor } \\
\text { professional } \\
\text { skepticism } \\
\end{array}$ & $\begin{array}{l}\text { Six characteristics of } \\
\text { skeptical professionals }\end{array}$ & $\begin{array}{l}\text { 7-point ordinal } \\
\text { numerical scale }\end{array}$ & 6 & Hurrt et al. (2013) \\
\hline $\begin{array}{l}\text { Client } \\
\text { satisfaction }\end{array}$ & $\begin{array}{l}\text { Three main constructs of } \\
\text { client satisfaction }\end{array}$ & $\begin{array}{l}\text { 7-point ordinal } \\
\text { numerical scale }\end{array}$ & 3 & Caruana (2002) \\
\hline
\end{tabular}

\subsection{Outlier Test}

Ferguson (1961) defined outliers as data that deviates from other data sets. Freeman, Barnett, and Lewis (1995) stated that "outliers are observations that do not follow most patterns and are located far from the data center." Sembiring (1995) defined outliers as observations that are far from the data center and may have a major effect on the regression coefficient.

Before the respondents' data was processed, the data was screened to determine whether there was outlier data that could affect the results. One method to determine outliers is the boxplot method using the quartile values. The quartile values are Quartile1, Quartile2, and Quartile3. The interquartile range (IQR) is defined as the difference between Quartile3 and Quartile1 or IQR = Q3-Q1. Outlier data can be determined by a value that is less than 1.5 against Quartile1 (lower limit); or Q1-1.5 (IQR) and a value that is more than 1.5 (IQR) against Quartile3 (upper limit), or Q3+1.5 (IQR). There were 265 respondents canvassed in this study, and there were 36 outliers, so the data from 229 respondents was processed.

\subsection{Model Specification}

The regression equation model for this research is:

$\mathrm{CS}=\alpha+\beta_{1} \mathrm{AI}+\beta_{2} \mathrm{AC}+\beta_{3} \mathrm{APS}+\varepsilon$

or

Client_Satisfaction $=\alpha+\beta_{1}$ Artificial_Intelligence $+\beta_{2}$ Auditor_Competency $+\beta_{3}$ Auditor_Professional_ Skepticism $+\varepsilon_{\mathrm{u}}$

\section{Results and Discussion}

\subsection{Sample Characteristics}

The population of this study comprised middle- and upper-level management companies listed on the Indonesia Stock Exchange (IDX) that have published audited financial reports for the 2019 period by one of the Big Four public accounting firms or public accountants of foreign-affiliated companies. Samples were selected using a purposive sampling method with specific criteria. The criteria determined by the researchers include middle- and upper-level management consisting of supervisors, managers, and senior accounting staff with at least three years' experience in the position, who have experience of audits by the Big Four public accounting firms or foreign-affiliated public accounting firms, and who have experience in auditing with AI, cognitive technology assistance, or audit software. 


\subsection{Analysis and Results (Outer Model and Inner Model)}

4.2.1. Inferential Analysis

Inferential analysis is a series of methods used to process data and test research hypotheses. In this study, the inferential analysis used parametric inferential statistical techniques assisted by analytical tools in accordance with the path analysis via the partial least squares structural equation modeling (PLS-SEM) SmartPLS version 3 .

The inferential analysis in this study was carried out in two stages. The first stage evaluates the measurement, or outer, model, and the second stage evaluates the structural, or inner, model. The evaluation in both stages uses reflective indicators only rather than formative indicators or a mixture of formative and reflective. The measurement model uses a latent construct with reflective indicators, so the validity and reliability of these indicators need to be tested. This study used five latent constructs and 18 indicators. Four evaluations of the measurement models or external models were obtained using the PLS algorithm. This procedure collectively generates the VIF, R-squared, f-squared, and path coefficient values used in the inner model evaluation.

\subsubsection{Outer Model Evaluation}

\subsubsection{Reliability of Model Indicators}

An indicator meets the reliability requirements if it has a loading value $>0.7$; this also shows that the construct can explain more than 50\% of the variance of the indicator (Hair, Sarstedt, Hopkins, and Kuppelwieser, 2014). Of the 18 indicators in the logarithmic coefficient path in this study, there were two indicators in the latent variable of professional auditor skepticism which were unreliable, thus a cut-off was carried out so that the reliable indicator for each latent variable is $>0.7$. The latent variable values are as follows:

AI: AI 1 (0.769), AI2 (0,747), AI3 (0.838), AI4 (0.831), AI5 (0.866)

Auditor Competence: AC1 (0.784), AC2 (0.798), AC3 (0.791), AC4 (0.745),

Auditor Professional Skepticism: APS3 (0.812), APS4 (0.810), APS5 (0.731), APS6 (0.833)

Client Satisfaction: CS1 (0.716), CS2 (0.754), CS3 (0.776).

\subsubsection{Internal Consistency Reliability Model}

A composite reliability value of $>0.7$ is considered good reliability. The composite reliability value for Artificial Intelligence is 0.905; Auditor Competence is 0.861; Auditor Professional Skepticism is 0.791; and Client Satisfaction is 0.882, all of which are > 0.7.

\subsubsection{Convergent Validity Model}

An average variance extracted (AVE) value of $>0.5$ or higher means that the construct can explain $50 \%$ or more of its item variance (Hair et al., 2014). The AVE value of the latent variable is 0.657; AC is 0.608; APS is 0.636 , and CS is 0.561 ; all of which are $>0.5$.

\subsubsection{Discriminant Validity}

The discriminant validity test in this study was carried out using the Fornell-Larcker criterion value. The Fornell-Larcker criterion is obtained by comparing the square root value of the AVE for each construct with the correlation between the other constructs in the model. A model with a good discriminant validity value can be concluded if the AVE square root of each construct is greater than the correlation value between the constructs in the model.

Table 2. Discriminant Value Model.

\begin{tabular}{l|c|c|c|c}
\hline Variable & AI & AC & APS & CS \\
\hline Artificial intelligence (AI) & 0.810 & & & \\
\hline Auditor competence (AC) & 0.353 & 0.780 & & \\
\hline Auditor professional skepticism (APS) & 0.602 & 0.584 & 0.798 & \\
\hline Client satisfaction (CS) & 0.537 & 0.487 & 0.602 & 0.749 \\
\hline
\end{tabular}

The data in Table 2 shows that the AI latent variable has an AVE square root value of 0.810 and this value is greater than the correlation value of the AI latent variable against other latent variables. The same is the case with the latent variables of AC (0.780), ASP (0.798) and CS (0.749), which also have an AVE square root value that is greater than the correlation value with other latent variables. Because each latent variable used in the study has an AVE square root value that is greater than the correlation value with other latent variables, all latent variables in this study are declared to meet the discriminant validity requirements. 


\subsubsection{Structural Model Evaluation (Inner Model)}

The initial stage of evaluating the structural model is to check the collinearity between the construct and the predictive ability of the model (Hair et al., 2014), followed by measuring the predictive ability of the model using the coefficient of determination $\left(\mathrm{R}^{2}\right)$, effect size $\left(f^{2}\right)$, and path coefficients.

\subsubsection{Variance Inflation Factor (VIF)}

Evaluation of the VIF aims to determine whether there is a collinearity relationship between the variables or constructs. The VIF value must be less than five; a value of more than five indicates collinearity between constructs. If the overall value of the indicators in each latent variable is less than five, then the research model can be declared free from multicollinearity and the data can be used for further research (Hair et al., 2014). The VIF values for the latent variables are as follows:

Artificial intelligence: AI 1 (1,760), AI2 (1.705), AI3 (2.100), AI4 ((2.182), AI5 (2.407)

Auditor Competence: AC1 (1.541), AC2 (1.672), AC3 (1.512), AC4 (1.539)

Auditor Professional Skepticism; APS3 (1.669), APS 4 (1.816), APS5 (1.449), APS6 (1.866)

Client Satisfaction; CS1 (1.201), CS2 (1.222), CS3 (1.215).

\subsubsection{Coefficient of Determination (R-squared)}

The coefficient of determination $\left(\mathrm{R}^{2}\right)$ is a way to estimate how much an endogenous construct can be explained by an exogenous construct. The expected coefficient of determination is between 0 and 1 . The $\mathrm{R}^{2}$ values of 0.75 , 0.50, and 0.25 mean that the model is strong, moderate, or weak, respectively (Hair et al., 2014). The $\mathrm{R}^{2}$ of client satisfaction is 0.471 , meaning that $47.1 \%$ of the client satisfaction construct can be explained by artificial intelligence, auditor competence and auditor professional skepticism; thus, it can be stated that the research model is moderate.

\subsubsection{Effect Size $(f)$}

The effect size in this study is used to assess the magnitude of the influence between variables. An $\mathrm{f}-$ squared value of 0.02 is small, 0.15 is moderate, and 0.35 is large. Values less than 0.02 either have a negligible effect or no effect. The $f$ effect of client satisfaction from the exogenous AI variable on client satisfaction is 0.061 , which is moderate; auditor competence on client satisfaction is 0.034 , which is moderate, and auditor professional skepticism on client satisfaction is 0.153 , which is large.

\subsubsection{Path Coefficients}

Measurement of the path coefficients between constructs is used to determine the significance and strength of the relationships between variables and to test the research hypothesis. The path coefficients range from -1 to +1 . The relation between the two constructs is considered positive if the path coefficient is closer to a +1 value. A relation closer to the value of -1 indicates that the relationship between the two constructs is negative (Hair et al., 2014).

The path coefficient from AI to client satisfaction is 0.231 , which is positive; from auditor competence to client satisfaction is 0.166 , which is positive; and from auditor professional skepticism to client satisfaction is 0.411 , which is also positive.

\subsection{Discussion}

This analysis produces a t-statistic value for each relationship path used to test the hypothesis. The tstatistic value will be compared with the t-table value. This study uses a $95 \%$ confidence level; therefore, the level of accuracy or the limit of inaccuracy $(\alpha)=0.05(5 \%)$, and the value of the t-table is 1.96 . If the t-statistic value is less than the t-table value $(\mathrm{t}$-statistic $<1.96)$ then Ho is accepted and Ha is rejected. Conversely, Ho is rejected and $\mathrm{Ha}$ is accepted if the t-statistic value is greater than or equal to the t-table (t-statistic $>1.96)$. The results of the hypothesis testing are shown in Table 3.

Table 3. Hypothesis structure model test.

\begin{tabular}{c|c|c|c|c|c}
\hline Description & $\begin{array}{c}\text { Original } \\
\text { sample (O) }\end{array}$ & $\begin{array}{c}\text { Mean sample } \\
(\mathbf{M})\end{array}$ & $\begin{array}{c}\text { Standard deviation } \\
(\mathbf{S T D E V})\end{array}$ & $\begin{array}{c}\text { t-statistic } \\
(\mathbf{O} / \mathbf{S T D E V})\end{array}$ & P-value \\
\hline $\mathrm{AI} \rightarrow \mathrm{CS}$ & 0.231 & 0.241 & 0.067 & 3.429 & 0.000 \\
\hline $\mathrm{AC} \rightarrow \mathrm{CS}$ & 0.227 & 0.228 & 0.062 & 3.637 & 0.000 \\
\hline $\mathrm{APS} \rightarrow \mathrm{CS}$ & 0.166 & 0.167 & 0.070 & 2.379 & 0.009 \\
\hline
\end{tabular}

Based on the path coefficient analysis using the SmartPLS version 3 bootstrapping procedure, the following results were obtained:

Testing the influence of AI on client satisfaction produced a statistical t-value of 3.429 , which is $>1.96$ ( $t$ table value), and a p-value of 0.000 , which is $<0.05(\alpha)$. The original sample/mean sample value is positive, so it can be stated that an AI auditor has a positive and significant effect on client satisfaction. The results of this study are in line with the findings of Ismail, Haron, Ibrahim, and Isa (2006), which state that the satisfaction of 
audit clients listed on the Malaysia Stock Exchange is influenced by tangibles. Mohanty, Seth, and Mukadam (2007) stated that AI creates an efficient and inexpensive work atmosphere and can lead to better audit quality. Audit quality can provide value to a company if it is conducted properly. A higher level of audit quality results in a high level of client satisfaction (Ohman et al., 2012), and client satisfaction is central to organizational success (Minton, 2015).

The first definition of AI was proposed by McCarthy, Minsky, Rochester, and Shannon (1955) as follows: "The goal of AI is to develop machines that behave as if they are intelligent. It is the science and engineering of intelligent machinery, especially intelligent computer programs." Nilsson (2009) defines AI as an activity aimed at making intelligent machines, and intelligence is a quality that enables entities to function appropriately and with foresight in their environment. There are two main research streams related to advances in AI. Services and technology literature tend to focus more on the positive side of using AI technology, whereas economic literature tends to focus on the effects of AI on jobs. Service literature tends to focus on smart technology applications (Colby, Mithas, \& Parasuraman, 2016; Marinova, de Ruyter, Huang, Meuter, \& Challagalla, 2017). AI offers a way to bridge the gap between data science and execution by filtering and analyzing large amounts of corrupt data that was once an insurmountable process.

Testing of the effect of auditor competence on client satisfaction obtained a t-statistic value of 3.637, which is $>1.96$ (t-table), a p-value of 0.000 , which is $<0.05(\alpha)$, and from the original sample/mean sample value, it can be stated that auditor competence has a positive and significant effect on client satisfaction. This research is in line with that of Ohman et al. (2012), who found that signing auditor competence has an effect on client satisfaction. Ali, Mail, and Amirul (2019) stated that auditor competence has a significant effect on client satisfaction. The level of client satisfaction is influenced by the client's internal factors, namely the client's feelings about the services provided and the confidence and competence of the auditor, while external factors come from the reputation of the auditor and the public accounting firm where the auditor works (Ohman et al., 2012).

The findings of Al Sawalqa (2014) also show that audit quality does not only depend on written rules and procedures, but also on technical capabilities and individual characteristics that form important factors for improving audit quality. Experienced auditors will make judgments with a lower error rate, which will affect their audit results. In addition, strong oversight will prevent the possibility of auditors from acting in a way that reduces audit quality, and closely monitored audits are likely to result in correct disclosure and higher audit quality.

This is in line with the opinion of Chadegani (2013), who states that the characteristics of individual auditors are the most important factors affecting audit quality. Thus, the competence of an auditor will determine the level of client satisfaction. Ismail et al. (2006) stated that respondents were satisfied with the quality of audit services from the tangible dimension. Furiady and Kurnia (2015) stated that auditor competence has a significant effect on audit quality, and Handayani and Merkusiwati (2015) stated that auditor competence has a positive effect on audit quality. Therefore, auditors must improve their competence to improve audit quality, which, in turn, will create client satisfaction.

Testing of the influence of the auditor professional skepticism variable on client satisfaction provided a statistical t-value of 2.379 , which is $>1.96$ (t-table value), a p-value of 0.009 , which is $<0.05(\alpha)$, and the original sample/mean sample value was positive, so it can be stated that auditor professional skepticism has a positive and significant effect on client satisfaction. Auditor professional skepticism is a determinant that is negatively related to client satisfaction. However, research conducted by Aschauer, Fink, Moro, Van BakelAuer, and Warming-Rasmussen (2017) found that identification by auditors has a positive effect on client perceptions and on auditor skepticism; ultimately, it can create client satisfaction. Ruiz et al. (2004) claimed that an auditor's decision-making regarding a company's survival comprises two stages, namely identifying the issues at stake (which is related to the auditor's competence) and deciding what to do (related to professional skepticism attitudes).

However, the study's findings are not consistent with the findings of Ohman et al. (2012), who found that audit skepticism negatively affects the satisfaction of the client. A higher level of skepticism from auditors will cause inconvenience for clients and impact their satisfaction. These findings are in line with Hurrt et al. (2013), who stated that professional skepticism is the basis for achieving high-quality audit performance. The auditor's professional skepticism or doubts regarding the client's verbal and written statements and information is part of the audit process. Kusumawati and Syamsuddin (2018) stated that professional skepticism has a significant direct effect on audit quality. Brown-Liburd, Cohen, and Trompeter (2013) argued that when auditors show high professional skepticism, they are more conservative and stand firmer than auditors who do not show high professional skepticism.

Ciołek (2017) claims that professional skepticism is fundamental to a high-quality audit performance. Therefore, auditors must increase professional skepticism to improve audit quality, which, in turn, creates client satisfaction. 


\section{Conclusion and Recommendation}

\subsection{Conclusion}

This study shows the use of AI, combined with the competence and professional skepticism of auditors, has a positive and significant effect on the satisfaction of clients of the Big Four public accounting firms and foreign-affiliated public accounting firms on the Indonesia Stock Exchange. According to the research results, the following conclusions can be drawn: 1) The use of AI has a positive and significant effect on client satisfaction. This has implications for improving audit quality. 2) Auditor competence has a positive effect on client satisfaction.

This implies the importance of auditors to continuously maintain and improve their competence. 3) Auditor professional skepticism has a positive and significant effect on client satisfaction. This implies the importance of auditors in preparing audit programs with a standardized critical assessment of the validity of audit evidence.

Audit programs for work procedures, and critical assessment standards in proving audit evidence, will have an impact on the credibility of the audit results. The credibility of financial statements that are audited with high skepticism will increase the trust of clients and other stakeholders. The client will be satisfied with the credibility of the audited financial statements if this principle of skepticism is applied to every audit program carried out.

\subsection{Recommendation}

This study had several limitations as the research process was carried out during the Covid-19 pandemic when the government imposed work from home rules, so it was difficult to obtain a large number of respondents. With this research limitation in mind, further research should be carried out in terms of AI tasks or the use of AI to improve audit quality with a larger amount of data under normal conditions and/or on a regional scale in Asia or ASEAN countries.

\section{References}

Affes, H. (2016). The impact of information and communication technologies on the professional performance of the external auditors in the Tunisian context. International Journal of Auditing Technology, 3(1), 63-78. https://doi.org/10.1504/ijaudit.2016.078173

Al Sawalqa, F. (2014). External audit services quality and client satisfaction: Evidence from Jordan. Research Journal of Finance and Accounting, 5(12), 223-236.

Ali, Z. M., Mail, R., \& Amirul, S. M. (2019). The mediation effect of clients' satisfaction between audit qualty and auditor retention of small and medium enterprises (SMES). International Journal of Accounting, 4(17), 53-65.

Armstrong, M., \& Baron, A. (1998). Performance management: The new realities. London: Institute of Personnel and Development.

Aschauer, E., Fink, M., Moro, A., Van Bakel-Auer, K., \& Warming-Rasmussen, B. (2017). Trust and professional skepticism in the relationship between auditors and clients: Overcoming the dichotomy Myth. Behavioral Research in Accounting, 29(1), 19-42. https://doi.org/10.2308/bria-51654

Atkinson, R. L., Atkinson, R. C., \& Hilgard., E. R. (2000). Introduction to psychology (13th ed., Vol. 3). New York: Harcourt College Publishers.

Behn, B. K., Carcello, J. V., Hermanson, D. R., \& Hermanson, R. H. (1997). The determinants of audit client satisfaction among clients of big 6 firms. Accounting Horizons, 11(1), 7-24.

Brennan, B., Baccala, M., \& Flynn, M. (2017). Artificial intelligence comes to financial statement audits. CFO.com (February 2). Retrieved from: http://ww2.cfo.com/auditing/2017/02/artificial-intelligence-audits/.

Brown-Liburd, H. L., Cohen, J., \& Trompeter, G. (2013). Effects of earnings forecasts and heightened professional skepticism on the outcomes of client-auditor negotiation. Journal of Business Ethics, 116(2), 311-325. https://doi.org/10.1007/s10551-012-1473-5

Burton, S., Sheather, S., \& Roberts, J. (2003). Reality or perception? Journal of Service Research, 5(4), $292-302$. https://doi.org/10.1177/1094670503005004002

Carcello, J. V., Hermanson, R. H., \& McGrath, N. T. (1992). Audit quality attributes: The perceptions of audit partners, preparers, and financial statement users. Auditing, $11(1), 1-15$.

Carlos, M. (2016). Artificial intelligence gets into auditing, what's next? Retrieved from: https://www.infoworld.com/article/3044468/artificial-intelligence-gets-into-auditing-whats-next.html.

Caruana, A. (2002). Service loyalty: The effects of service quality and the mediating role of customer satisfaction. European Journal of Marketing, 36(7/8), 811-828. https://doi.org/10.1108/03090560210430818

Chadegani, A. A. (2013). Review of studies on audit quality. Available at SSRN: https://ssrn.com/abstract=2227359.

Ciołek, M. (2017). Professional skepticism in auditing and its characteristics. Scientific works of the University of Economics in Wroclaw, 474, 33-34. https://doi.org/10.15611/pn.2017.474.03

Colby, C. L., Mithas, S., \& Parasuraman, A. (2016). Service robots: How ready are consumers to adopt and what drives acceptance? Paper presented at the In The 2016 Frontiers in Service Conference. Norway: Bergen.

Davenport, T. H. (2018). From analytics to artificial intelligence. Journal of Business Analytics, 1(2), 73-80. https://doi.org/10.1080/2573234x.2018.1543535

DeAngelo, L. E. (1981). Auditor size and audit quality. Journal of Accounting and Economics, 3(3), 183-199.

Ferguson, T. S. (1961). Rules for rejection of outliers. Review of the International Statistical Institute, $29(3), 29$. https://doi.org/10.2307/1401948 
Freeman, J., Barnett, V., \& Lewis, T. (1995). Outliers in statistical data. The Journal of the Operational Research Society, 46(8), 1034. https://doi.org/10.2307/3009915

Furiady, O., \& Kurnia, R. (2015). The effect of work experiences, competency, motivation, accountability and objectivity towards audit quality. Procedia - Social and Behavioral Sciences, 211, 328-335. https://doi.org/10.1016/j.sbspro.2015.11.042

Gibson, J. L., Ivancevich, J. M., James, H., \& Donnelly, J. (1994). Organizations: Bahavior, structure, processes. Homewood.

Hair, J. F., Sarstedt, M., Hopkins, L., \& Kuppelwieser, V. G. (2014). Partial least squares structural equation modeling (PLS-SEM): An emerging tool in business research. European Business Reviere, 26(2), 106-121. https://doi.org/10.1108/EBR-10-2013-0128

Halim, A. (2014). Audit time budget and professional commitment as moderating variables effect of auditor competence and independence on audit quality. Paper presented at the Lombok XVII National Accounting Symposium 2014.

Halim, A., Sutrisno, T., \& Achsin, M. (2014). Effect of competence and auditor independence on audit quality with audit time budget and professional commitment as a moderation variable. International Journal of Business and Management Invention, 3(6), 64-74.

Handayani, K., \& Merkusiwati, L. (2015). Effect of auditor independence and auditor competence on auditor professional skepticism and its implications for audit quality. E-Journal of Accounting, 1O(1), 229-243.

Harriet, A. (2016). Auditing: Pitch battle. Retrieved from: https://www.ft.com/content/268637f6-15c8-11e6-9d9800386a18e39d.

Humphrey, R. H., \& Ashforth, B. (1994). Cognitive scripts and prototypes in service encounters. Advances in Services Marketing and Management, 3(C), 175-199. https://doi.org/10.1016/s1067-5671(94)03018-9

Hurrt, R., Brown, 1. H., Early, C., \& Krishnamoorthy, G. (2013). Research on auditor professional skepticism: Literature synthesis and opportunities for future research. Auditing: A Journal of Practice and Theory, 32(1), 45-97. https://doi.org/10.2308/ajpt-50361

Iddrisu, A. M., Nooni, I. K., Fiankoc, K. S., \& Mensah, W. (2015). Assesing the impact of service quality on custumer loyalty: A case study of the cellular industry of Ghana, machine learning view project. Retrieved from www.eajournals.org

Ismail, I., Haron, H., Ibrahim, D. N., \& Isa, S. M. (2006). Service quality, client satisfaction and loyalty towards audit firms. Managerial Auditing Journal, 21(7), 738-756. https://doi.org/10.1 108/02686900610680521

Jenkins, J. G., \& Lowe, D. J. (2011). Auditors as advocates for their clients: Perceptions of the auditor-client relationship. Journal of Applied Business Research, 15(2), 73-78. https://doi.org/10.19030/jabr.v15i2.5680

Kerlinger, F. N., \& Lee, H. B. (2000). Foundations of behavioral research. Belmont: Wadsworth, California, USA.

Kokina, J., \& Davenport, T. H. (2017). The emergence of artificial intelligence: How automation is changing auditing. Journal of Emerging Technologies in Accounting, 14(1), 115-122. https://doi.org/10.2308/jeta-51730

Krech, D., Crutchfield, R. S., \& Livson, N. (1974). Elements of psychology (3rd ed.): Knopf.

Kusumawati, A., \& Syamsuddin, S. (2018). The effect of auditor quality to professional skepticsm and its relationship to audit quality. International Journal of Law and Management, 60(4), 998-1008. https://doi.org/10.1108/IJLMA-032017-0062

Langton Robbins, N. S. (2006). Organizational behavior (4th ed.). Toronto, Ontario: Pearson Prentice Hall, USA.

Libby, R., \& Tan, H.-T. (1994). Modeling the determinants of audit expertise. Accounting, Organizations and Society, 19(8), 701-716. https://doi.org/10.1016/0361-3682(94)90030-2

Lovelock, C., \& Patterson, P. (2015). Services marketing. Retrieved from https://books.google.co.id/books?hl=id\&lr=\&id=BqyaBQAAQBAJ\&oi=fnd\&pg=PP $1 \& d q=$ Lovelock+and + Patt erson\&ots=eIAVFNz 1 Gh\&sig=KDz6lg9xRKCMxcCfloFh2AaQZQ\&redir_esc $=\mathrm{y} \# \mathrm{v}=$ onepage $\& \mathrm{q}=$ LovelockandPatterson $\& \mathrm{f}=$ false.

Marinova, D., de Ruyter, K., Huang, M.-H., Meuter, M. L., \& Challagalla, G. (2017). Getting smart: Learning from technology-empowered frontline interactions. Journal of Service Research, 20(1), 29-42. https://doi.org/10.1177/1094670516679273

McCarthy, J., Minsky, M., Rochester, N., \& Shannon, C. (1955). A proposal for the dartmouth summer research project on artificial intelligence, august 31, 1955. AI Magazine, 27(4), 12-12. https://doi.org/10.1609/aimag.v27i4.1904

Minton, E. A. (2015). In advertising we trust: Religiosity's influence on marketplace and relational trust. Journal of Advertising, 44(4), 403-414

Mohanty, R., Seth, D., \& Mukadam, S. (2007). Quality dimensions of e-commerce and their implications. Total Quality Management \& Business Excellence, 18(3), 219-247. https://doi.org/10.1080/14783360601149992

Nilsson, N. J. (2009). The quest for artificial intelligence: Cambridge University Press.

Ohman, P., Häckner, E., \& Sörbom, D. (2012). Client satisfaction and usefulness to external stakeholders from an audit client perspective. Managerial Auditing Journal, 27(5), 477-499. https://doi.org/10.1 108/02686901211227995

Pandit, G. M. (1999). Clients' perceptions of their incumbent auditors and their loyalty to the audit firms: An empirical study. The Mid-Atlantic Journal of Business, 35(4), 171

Parasuraman, A., Zeithaml, V. A., \& Berry, L. L. (1994). Alternative scales for measuring service quality: A comparative assessment based on psychometric and diagnostic criteria. Journal of Retailing, 70(3), 201-230. https://doi.org/10.1016/0022-4359(94)90033-7

Presswire. (2016). PwC wins "audit innovation of the year" at the accountant \& international accounting bulletin awards 2016. Retrieved from https://www.m2.com/m2/web/story.php/20166219039.

Raphael, J. (2015). How artificial intelligence can boost audit quality. Retrieved from https://www.cfo.com/auditing/2015/06/artificial-intelligence-can-boost-audit-quality/.

Rodgers, W., Mubako, G. N., \& Hall, L. (2017). Knowledge management: The effect of knowledge transfer on professional skepticism in audit engagement planning. Computers in Human Behavior, 70, 564-574. https://doi.org/10.1016/j.chb.2016.12.069 
Ruiz, B. E., Gomez-Aguilar, N., De Fuentes-Barbera, C., \& Garcia-Benau, M. A. (2004). Audit quality and the going concern decision making process. European Accounting Review, 13(4), 597-620. https://doi.org/10.1080/09638180420002 16820

Sekaran, U., \& Bougie, R. (2016). Research method for business (7th ed.). Chichester, West Sussex: Printer Trento Srl.

Sembiring, R. K. (1995). Regression analysis (pp. 62). Bandung: ITB, Indonesia.

The Institute of Internal Auditors. (2017). Global perspectives adn insights Insights. Retrieved from www.theiia.org/gpi.

Warming-Rasmussen, B., \& Jensen, L. (1998). Quality dimensions in external audit services-an external user perspective. European Accounting Review, 7(1), 65-82. https://doi.org/10.1080/096381898336583

Windsor, C. A., \& Ashkanasy, N. M. (1995). The effect of client management bargaining power, moral reasoning development, and belief in a just world on auditor independence. Accounting, Organizations and Society, 20(7-8), 701-720. https://doi.org/10.1016/0361-3682(95)00018-5 